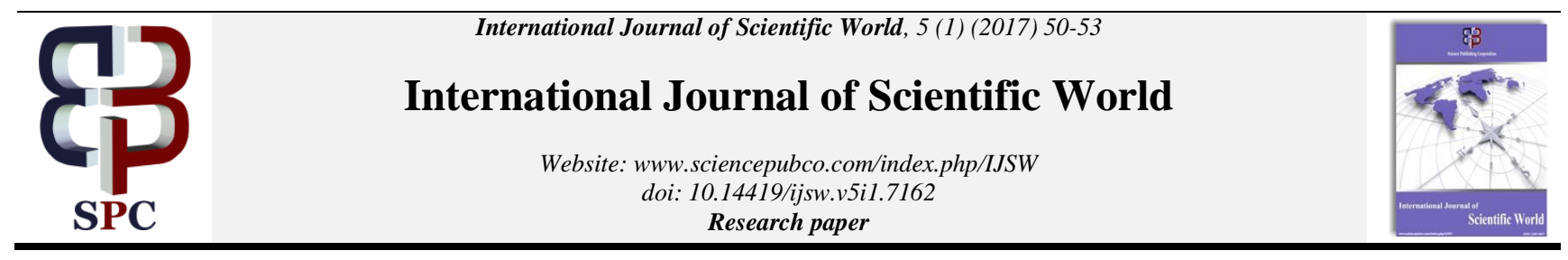

\title{
Distribution and conservation status of fishes reported from Muntjibpur pond of Allahabad (U.P.)
}

\author{
Ashok Kumar Verma* \\ Department of Zoology, Government Post Graduate College, Saidabad-Allahabad-221508 (U. P.), India \\ *Corresponding authorE-mail:akv.apexz@gmail.com
}

\begin{abstract}
Muntjibpur pond was studied to find out the conservation status of the fishes naturally occurring in it. The survey was conducted from July 2014 to June 2015. During exploration, a total of 13 species of fishes belonging to 12 genera, 8 families and 5 orders were identified. As per latest version of IUCN Red List, out of 13 species of fishes identified, 1 species comes under UV (vulnerable), 1 under NT (near threatened), 8 under LC (least concern) and 3 species are NE (not evaluated) so far. No fish species identified here comes under EN (endangered) category.
\end{abstract}

Keywords: Fish Species and Genera; Family; Order; Conservation Status; IUCN Red List; Muntjibpur Pond.

\section{Introduction}

Ichthyology is a branch of Zoology, which commonly deals with the study of fishes. Fishes are cold-blooded, gill-bearing aquatic craniate vertebrates that include both the bony and the cartilaginous fishes but sometimes jawless fishes too. Fish lives in the water and breathe by absorbing oxygen through their gills.

Fishes are since cold-blooded animals, so their internal body temperature is influenced by the environment. Many fishes have scales and use their fins to swim. Fish have a spine but do not have external ears or eyelids. Fish also have air bladders, which keep them afloat.

They belong to phylum: Chordata, subphylum: Vertebrata and super class: Pisces. India's most of population depends upon agriculture including pisciculture. Fishes are important to humans as a nutrient source of low-fat, high-quality protein. Fish and fish products are consumed as food all over the world.

It is also a good source of omega-3 fatty acids, vitamin D, vitamin $\mathrm{B}_{2}$, calcium, phosphorus, iodine, iron, zinc, magnesium and potassium, which are essential for healthy living.

Fish habitats are important to our environment because these no doubt constitute a part of the natural ecosystem and food chain. The fishes also provide huge ecological, cultural and economic values through food fisheries, recreational fisheries and commercial fisheries. Fish diversity is a good study material for workers associated with limnology and ichthyology.

The fishes are more than the combined total of all other vertebrate species: mammals, amphibians, reptiles and birds. Fish species diversity is roughly divided equally between marine (oceanic) and freshwater ecosystems.

Limnological studies as well as studies on fish biodiversity in a fresh water body were conducted by [1-8]. Hydrobiological studies and preliminary survey of fishes of Muntjibpur pond were performed by [9-10]. The present study is undertaken from Jul 2014 to Jun 2015 to find out the conservation status of fishes already reported from Muntjibpur pond of Allahabad.

\section{Study area}

Muntjibpur pond is a natural pond, located on north side of village Muntjibpur (Image1). This pond (photo 1) is surrounded by agricultural fields, road, garden and covers more than 5000 square meters. The study area is well connected by famous GT road through a minor link road. It is located in Pratap pur block of Phoolpur tahsil of Allahabad district of Uttar Pradesh and is more than $25 \mathrm{~km}$ away from Allahabad headquarter. This village is surrounded by Miraipur in east, Fatuhan in west, Saidpur in north and Fulahan in south. It is situated at latitude $25^{\circ} 25^{\prime} 55.16^{\prime \prime} \mathrm{N}$ and longitude $82^{\circ} 03$ ' $13.16^{\prime \prime} \mathrm{E}$.

The pond studied has good biodiversity as it is rich both in flora and fauna including fishes, planktons etc. The occurrence of good bio-diversity is an index of healthy, growing, dynamic and economically efficient water body.

\section{Material and methods}

Muntjibpur pond was surveyed and studied in detail for hydrobiological properties and fishes, once in a month for the period of one year from July 2014 to Jun 2015. The fishes were caught and collected for present survey from Muntjibpur pond by hand-nets, gill nets, cast nets, hooks, drag nets with the help of local people and fisherman.

Fishes were identified using the standard keys of [11-15]. People of local communities of adjoining areas also assisted the author in many ways for fish collection and identification. 


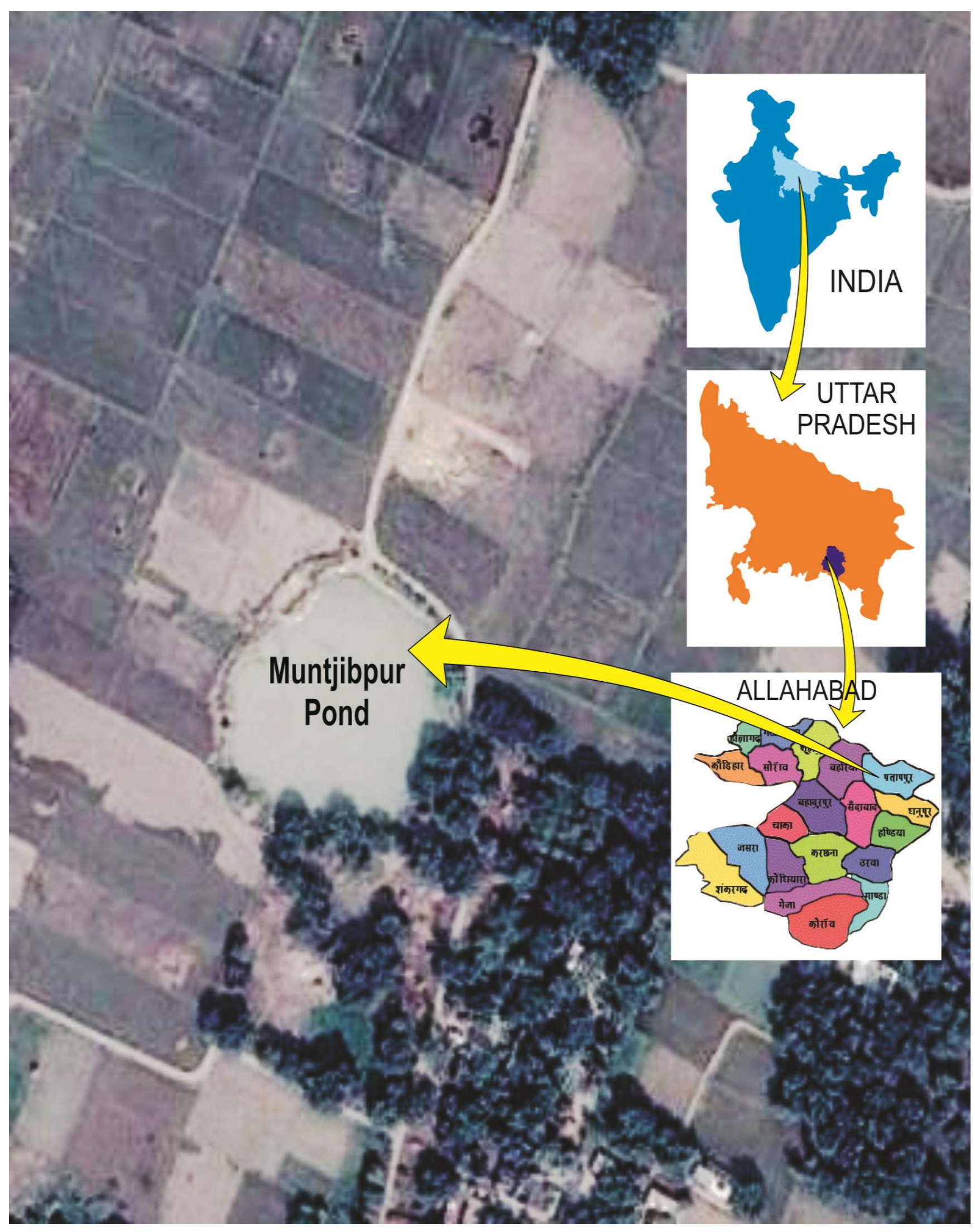

Fig. 1: Location of Study Area.

\section{Result and discussion}

During the entire study period, a total of 13 species of fishes of 12 genera belonging to 8 families and 4 orders were recorded from the Muntjibpur pond. The collected and identified fish species including their zoological names, family, order and conservation status are shown in the table given. 
Table 1: Showing Fishes and Their Conservation Status Reported from Muntjibpur Pond in the Year 2014-15

\begin{tabular}{llll}
\hline S.No. & Zoological name & Family & Order \\
\hline 1. & Catla catla & Cyprinidae & Cypriniformes \\
2. & Labeo rohita & Cyprinidae & Cypriniformes \\
3. & Labeo calbasu & Cyprinidae & Cypriniformes \\
4. & Cyprinus carpio & Cyprinidae & Cypriniformes \\
5. & Puntius ticto & Cyprinidae & Cypriniformes \\
6. & Mystus seenghala & Bagridae & Siluriformes \\
7. & Rita rita & Bagridae & Siluriformes \\
8. & Wallago attu & Siluridae & Siluriformes \\
9. & Clarias batrachus & Clariidae & Siluriformes \\
10. & Heteropneustes fossilis & Saccobranchidae & Siluriformes \\
11. & Channa punctatus & Ophiocephalidae & Ophiocephaliformes \\
12. & Gudusia chapra & Clupeidae & Clupeiformes \\
13. & Notopterus notopterus & Notopteridae & Osteoglossiformes \\
\hline
\end{tabular}

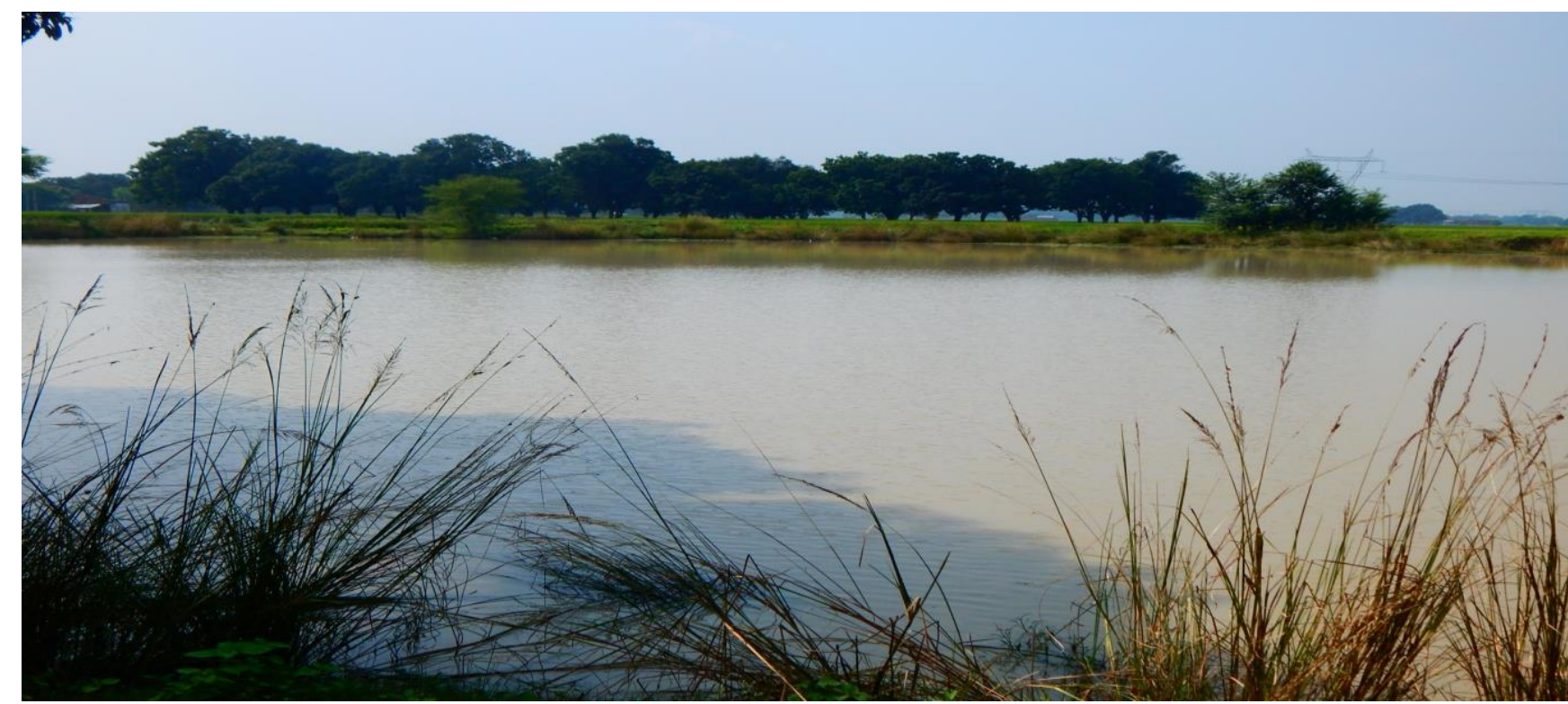

Fig1: A View of Study Area of Muntjibpur Pond.

On the basis of rate of decline, population size, area of geographic distribution and degree of population, distribution fragmentation etc., IUCN (International Union for Conservation of Nature) Red List [16] classified the species into nine groups including EW (Extinct in the wild), CR (Critically endangered), EN (Endangered), VU (Vulnerable), NT (near threatened), LC (least concern), DD (Data deficient) and NE (not evaluated).

During exploration, a total of 13 species of fishes belonging to 12 genera, 8 families and 5 orders were identified. As per latest version of IUCN Red List, out of 13 species of fishes identified, 1 species comes under UV (vulnerable), 1 under NT (near threatened), 8 under LC (least concern) and 3 species are NE (not evaluated) so far. No fish species identified here comes under EN, CR and EW categories.

\section{Conclusion}

Fishes of five orders namely Siluriformes, Cypriniformes, Ophiocephaliformes, Osteoglossiformes and Clupeiformes are collected and identified from this Muntjibpur pond. In present investigation, a total of 13 species of fishes belonging to 12 genera, 8 families and 5 orders were recorded. As far as their conservation status is concerned, out of 13 species of fishes identified, 1 species comes under UV (vulnerable), 1 under NT (near threatened), 8 under LC (least concern) and 3 species are NE (not evaluated) so far. The water present in the said pond is useful for irrigation as well as fish culture. The water quality of this pond is although having some pollution but is suitable for agricultural purposes also, as it is rich in organic humus, planktons and nutrients.

\section{Acknowledgements}

Author is highly grateful to the Prof. Ashish Joshi, Principal, Government Post Graduate College, Saidabad- Allahabad (Uttar Pradesh) for providing necessary laboratory facilities. The author is also obliged to my senior colleague Dr Shri Prakash, local people, Gram Pradhan and some unquoted persons for their co-operation during entire survey and research work.

\section{References}

[1] Prakash S., Verma A.K., and Prakash S. (2015a). Limnological Studies of Alwara Lake of Kaushambi (U.P.). International Journal on Biological Sciences. 6 (2): 141-144 pp.

[2] Prakash S., Verma A.K. (2015b). Studies on different fish genera in Alwara Lake of Kaushambi. Bioherald: An International Journal of Biodiversity \& Environment. 5(1-2): 60-62 pp.

[3] Prakash S., Verma A.K., Prakash S. (2015c).Seasonal variation of Zooplankton and Zoobenthos Population in Alwara Lake of District Kaushambi (UP) India. The Journal of Zoology Studies. 2(5):13-16 pp.

[4] Prakash S., Verma A.K. (2016). Conservation status of fresh water fishes reported in Alwara Lake of District Kaushambi (U.P.). International Journal of Zoology Studies. 1(5): 25-27 pp. 
[5] Verma A.K. and Prakash S.(2016a). Fish biodiversity of Alwara lake of District Kaushambi, Uttar Pradesh, India. Research Journal of Animal, Veterinary and Fishery Sciences.4 (4): 5-9 pp.

[6] Verma A.K., Kumar S. and Prakash S. (2016b). Seasonal Correlation between physico-chemical factors and phytoplankton density in Alwara taal of Kaushambi, U. P., India. International Research Journal of Biological Sciences. 5 (3):40-45 pp.

[7] Verma A.K. (2016a). Dominancy of Cypriniformes fishes in Alwara lake of District Kaushambi (U.P.). International Journal on Agricultural Sciences. 7 (1): 89-91 pp.

[8] Verma A.K. (2016b). Distribution and Conservation Status of Catfishes in Alwara Lake of District Kaushambi (U.P.). International Journal on Environmental Sciences.7 (1): 72-75 pp.

[9] Verma A.K. (2016c).Hydrobiological Studies of Muntjibpur Pond of Allahabad (U.P.) International Journal on Agricultural Sciences. 7 (2): 164-166 pp.

[10] Verma A.K. (2016d).A Preliminary Survey of Fresh Water Fishes in Muntjibpur Pond of Allahabad (U.P.). Indian Journal of Biology. 3(2). pp. 99-101.https://doi.org/10.21088/ijb.2394.1391.3216.2.

[11] Mishra K.S. (1959). An aid to identification of the common commercial fishes of India and Pakistan. Record Indian Museum.

[12] Day F. (1989). The fauna of British India including Ceylon and Burma. Fishes Taylor and Francis, London

[13] Jhingran V.G. (1991). Fish and Fisheries of India. Hindustan Publishing Corporation, Delhi, India.

[14] Jayaram K.C. (1999). The freshwater fishes of the Indian region. Narendra Publishing House, Delhi-110006, India.

[15] Srivastava Gopalji (1998). Fishes of U.P. and Bihar, Vishwavidalaya Prakashan Chowk, Varanasi, India.

[16] The IUCN Red List of Threatened Species (2016). Version 2015-4. <www.iucnredlist.org>. Downloaded on 25 March 2016. 